\title{
The Application of CAPM As A Basis For Determining The Return Level, Risk To Determine The Efficient Stock Group On Companies Listed On Indonesia Stock Exchange
}

\author{
Anastasya Dyah Puspita ${ }^{1}$, Muhaimin Dimyati $^{2}$, Ratih Rachmawati ${ }^{3}$ \\ Student STIE Mandala Jember ${ }^{1}$, Lecturer, STIE Mandala Jember ${ }^{2,3}$ \\ Email: dimyati@stie-mandala.ac.id ${ }^{2}$
}

\begin{abstract}
Along with the increasing interest of the public to invest in the capital market, the analytical ability of an investor is needed in determining investment options. CAPM is a balance model that describes the relationship between risk and returns where risk is measured using beta. This research was conducted on food and baverage company period 2013-2016. The analytical method used is descriptive statistics. The results showed that there was a positive or linear relationship between expected rate of return and systematic risk. There are 4 shares with negative individual return. From 14 companies, there are 8 shares that include the efficient stock groups: AISA, CEKA, INDF, PSDN, SKBM, SKLT, STTP, ULTJ. 6 shares that include inefficient stock groups are: ALTO, DLTA, ICBP, MLBI, MYOR, ROTI. An efficient share is a stock with an individual rate of return higher than the expected rate of return The investment decision taken is to buy the stock efficiently (undervalued) and hold it and then sell back when the prices rise. For the inefficien shares (overvalue) is to sell the stock before the price goes down.
\end{abstract}

Keywords: CAPM, return, risk, beta

\section{INTRODUCTION}

To encourage people to become investors in the capital market, the Indonesia Stock Exchange (IDX) held a "Let's Save Stock" campaign to invite people as potential investors to invest in the capital market by buying shares regularly and periodically with the aim of increasing the number of new investors and increasing the number of active investors in the Indonesian capital market. Based on the results of a national survey of financial literacy and inclusion of 
the financial services authority in 2016, the level of public understanding or literacy of the capital market rose to $4.40 \%$ and data for December 2016 shows the number of active investors in Indonesia per year has increased to $35 \%$ of total market investors. capital in Indonesia. The Indonesia Stock Exchange (IDX) recorded a net profit for the 2016 financial year reaching 344.8 billion, jumping 192.37 percent compared to the previous year's achievement of 118.78 billion.

Along with the increasing public interest in investing in the capital market, an investor's analytical skills are needed in determining investment options. To make an investment in the capital market, sufficient knowledge, experience, and business instincts are needed to analyze the securities to be purchased, which ones will be sold., and which ones will remain. The basis for investment decisions consists of the expected rate of return, the level of risk and the relationship between return and risk. The aim of investors in investing is to maximize returns without forgetting the investment risk factors that they must face.

CAPM is a balance model that describes the relationship between risk and rate of return (return) where risk is measured using beta. This method can be used by investors to determine efficient stocks that provide maximum returns or investments that provide returns with the least risk. CAPM aims to assist investors in selecting stocks and determining the best investment options or deemed appropriate to have in a Food and Beverage company listed on the IDX in terms of returns and risks which can then be used as a basis for diversifying shares. This study aims to analyze the rate of return of individuals, the expected rate of return and the risk of the Food and Bevergae companies listed on the IDX for the period 2013-2016. Next, how to classify efficient and inefficient stocks in Food and Beverage companies listed on the IDX for the 2013-2016 period.

\section{RESEARCH METHODS}

This research was conducted at Food and Baverage companies listed on the IDX for the period 2013-2016. The sampling method used was purposive sampling method. This type of research is a quantitative descriptive study. Descriptive research is research conducted to describe the

independent variables, either one or more variables without making comparisons, or connecting one variable to another. Research carried out on the entire population or without taking samples will use descriptive in the population (Sugiyono, 2016). This study uses 
secondary data using data collection methods, namely documentation. Data sources were obtained from www.idx.co.id, www.bi.go.id, and www.yahoofinance.com.

The analytical method used is descriptive statistics. Descriptive statistical analysis is statistics used to analyze data by describing or describing the collected data as it is without intending to make generalized conclusions or generalizations. Descriptive statistics include the presentation of data through tables, graphs, average calculations, etc. (Sugiyono, 2016).

The stages of data analysis in this study are:

1. Calculate the rate of return on individual stocks

Is the rate of return that investors expect on investment which is conducted.

2. Calculating the market rate of return

The market rate of return can be calculated through the development of the stock price index.

3. Calculate the risk-free rate of return

According to Jogiyanto Hartono (2010) the risk-free rate of return is a certain expected rate of return or return with a risk equal to zero or the future rate of return can be ascertained at this time. On the basis of measurement, namely the level of the tribe

SBI interest.

4. Calculating the risk systematically

According to Zarah Puspitaningtyas (2015), stock risks are

symbolized by beta $(\beta)$ is a systematic risk and it is this risk

which is associated with the expected rate of return. CAPM model

states that the greater the beta $(\beta)$, the greater the level

returns on shares acquired by investors. Beta shows the level

the sensitivity of the overall share price in the market..

5. Calculate the expected rate of return

According to Dermawan Sjahrial (2014), the expected rate of return is the return expected by investors in the future. 


\section{Draw the Security Market Line}

Security Market Line is a line that connects the expected rate of return of a security with systematic risk (beta).

7. Efficient Stock Grouping and investment decisions

\section{RESULT AND DISCUSSION}

\section{RESEARCH RESULT}

This study discusses the application of CAPM as a basis for determining the rate of return (return), the risk of determining efficient stock groups in food and beverage companies listed on the IDX 2013-2016

The population in this study were all food and beverage companies for the period 2013-2016. Because all food and beverage companies have or have met the predetermined criteria, the sample in this study used the entire population.

\section{Individual Rate of Return}

The rate of return (return) is the total profit or loss from an investment in a certain period which is calculated by dividing the value of changes in assets in a certain period by the initial investment value or the stock price in period t minus the share price in the previous period $(\mathrm{t}-$ 1) divided by the price. previous period shares ( $\mathrm{t}-1)$. A positive return is considered a gain or capital gain while a negative return means a loss or capital loss (Sjahrial, 2014).

Table 2. Individual Returns

\begin{tabular}{|c|c|c|}
\hline NO & Stock code & Ri \\
\hline 1 & AISA & 0,016928 \\
\hline 2 & ALTO & 0,002401 \\
\hline 3 & CEKA & 0,011697 \\
\hline 4 & DLTA & 0,021059 \\
\hline 5 & ICBP & 0,008529 \\
\hline 6 & INDF & 0,008526 \\
\hline 7 & MLBI & 0,002448 \\
\hline 8 & MYOR & 0,000556 \\
\hline 9 & PSDN & 0,004221 \\
\hline 10 & ROTI & 0,005440 \\
\hline
\end{tabular}




\begin{tabular}{ccc}
\hline $\mathbf{1 1}$ & SKBM & 0,017865 \\
\hline $\mathbf{1 2}$ & SKLT & 0,024882 \\
\hline $\mathbf{1 3}$ & STTP & 0,035409 \\
\hline $\mathbf{1 4}$ & ULTJ & 0,027153 \\
\hline AVG & & $\mathbf{0 , 0 0 9 1 9 2}$ \\
\hline
\end{tabular}

Based on table 2 shows that the majority of companies are sampled has a positive rate of return on individual stock. Based on the 14 shares of the companies sampled, all of them have value the average rate of return on individual stocks is 0.009192 or $0.92 \%$. The company shares that have the highest individual stock returns are PT. Siantar Top Tbk (STTP) which is equal to 0.035409 or $3.54 \%$ and shares with individual stock returns (the lowest is PT. Delta Djakarta Tbk (DLTA) which is -0.021059 or $-2.11 \%$.

\section{Market Return}

The market rate of return can be calculated through the development of the stock price index. Period t market return is calculated by the Stock Price Index. The combined period t (IHSGt) minus the previous period Composite Stock Price Index (IHSG - 1) divided by the previous period Composite Stock Price Index (IHSG - 1). The index describes the market movement trend or describes the overall stock market performance. If the market Return is of value positive indicates that the index has increased during the period otherwise if the market return is negative it indicates that the index has fallen or decreased.

Table 3. Market Return

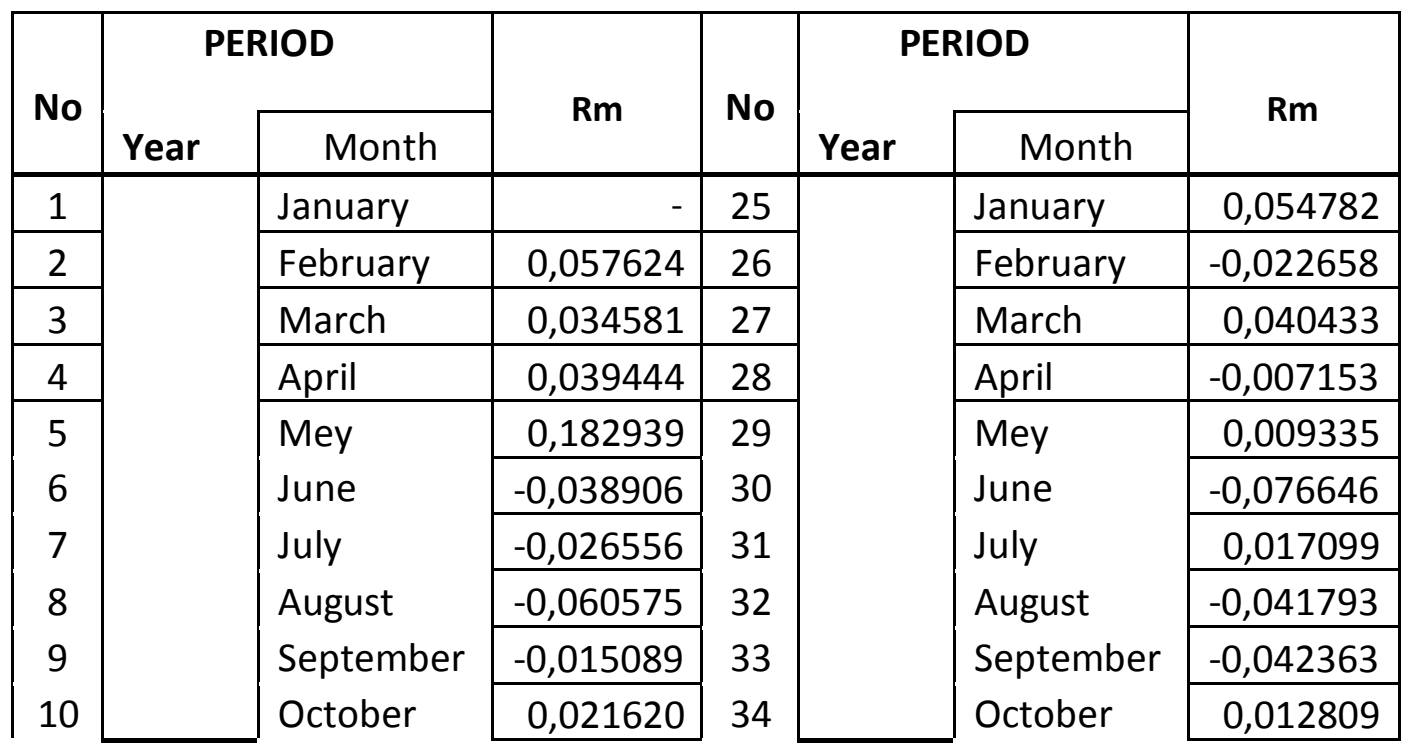




\begin{tabular}{|c|c|c|c|c|c|c|c|}
\hline 11 & \multirow[b]{2}{*}{2013} & \multirow{2}{*}{$\begin{array}{l}\text { November } \\
\text { December }\end{array}$} & $-0,071196$ & \multirow{2}{*}{$\begin{array}{l}35 \\
36 \\
\end{array}$} & \multirow[b]{2}{*}{2015} & \multirow{2}{*}{$\begin{array}{l}\text { November } \\
\text { December }\end{array}$} & 0,016812 \\
\hline 12 & & & 0,013824 & & & & $-0,006065$ \\
\hline 13 & & January & 0,059823 & 37 & & January & 0,051784 \\
\hline 14 & & February & 0,037836 & 38 & & February & 0,097636 \\
\hline 15 & & March & 0,005051 & 39 & & March & $-0,039503$ \\
\hline 16 & & April & 0,022258 & 40 & & April & 0,017059 \\
\hline 17 & & Mey & $-0,010884$ & 41 & & Mey & $-0,004848$ \\
\hline 18 & & June & 0,007977 & 42 & & June & 0,025916 \\
\hline 19 & & July & 0,034544 & 43 & & July & $-0,000778$ \\
\hline 20 & & August & $-0,006865$ & 44 & & August & 0,050579 \\
\hline 21 & & September & 0,032797 & 45 & & September & $-0,014704$ \\
\hline 22 & & October & $-0,020759$ & 46 & & October & 0,005726 \\
\hline 23 & 2014 & November & 0,025235 & 47 & 2016 & November & $-0,057220$ \\
\hline 24 & & December & 0,018167 & 48 & & December & $-0,003191$ \\
\hline & & & JUMLAH & & & & 0,425937 \\
\hline & & & RATA RATA & & & & 0,009062 \\
\hline
\end{tabular}

Based on table 3 the average market rate of return $(\mathrm{Rm})$ in $2013-2016$ is 0.009062 or $0.91 \%$. The highest market rate of return occurred in May 2013 amounting to 0.182939 or $18.3 \%$ and the lowest rate of return occurred in June 2015 amounting to -0.076646 or $-7.66 \%$

\section{Risk-free return}

Risk-free return is the expected return that has the risk $(\beta)$ equal to zero or future returns that can be assumed at this time. Risk-free return is measured based on the interest rate for Bank Indonesia Certificates (SBI) (Tandelilin, 2010). According to Irham Fahmi (2015), the reason SBI is always considered safe is because the government always secures every banking institution that is directly under its supervision.

Risk-free return is calculated by dividing the average number of SBI interest rates during 2013-2016 then divided by the number of months in one year. The risk-free return values are as follows: $0.068854 \mathrm{R}=12$

\section{Beta}

$\mathrm{Rf}=0.005738$

The Capital Assets Pricing Model (CAPM) uses beta as a measure systematic risk that cannot be eliminated through diversification. Beta shows the relationship or stock movement with the market or the stock as a whole (Fahmi, 2015). 
Table 4. Beta

NO

Code of Stock

BETA

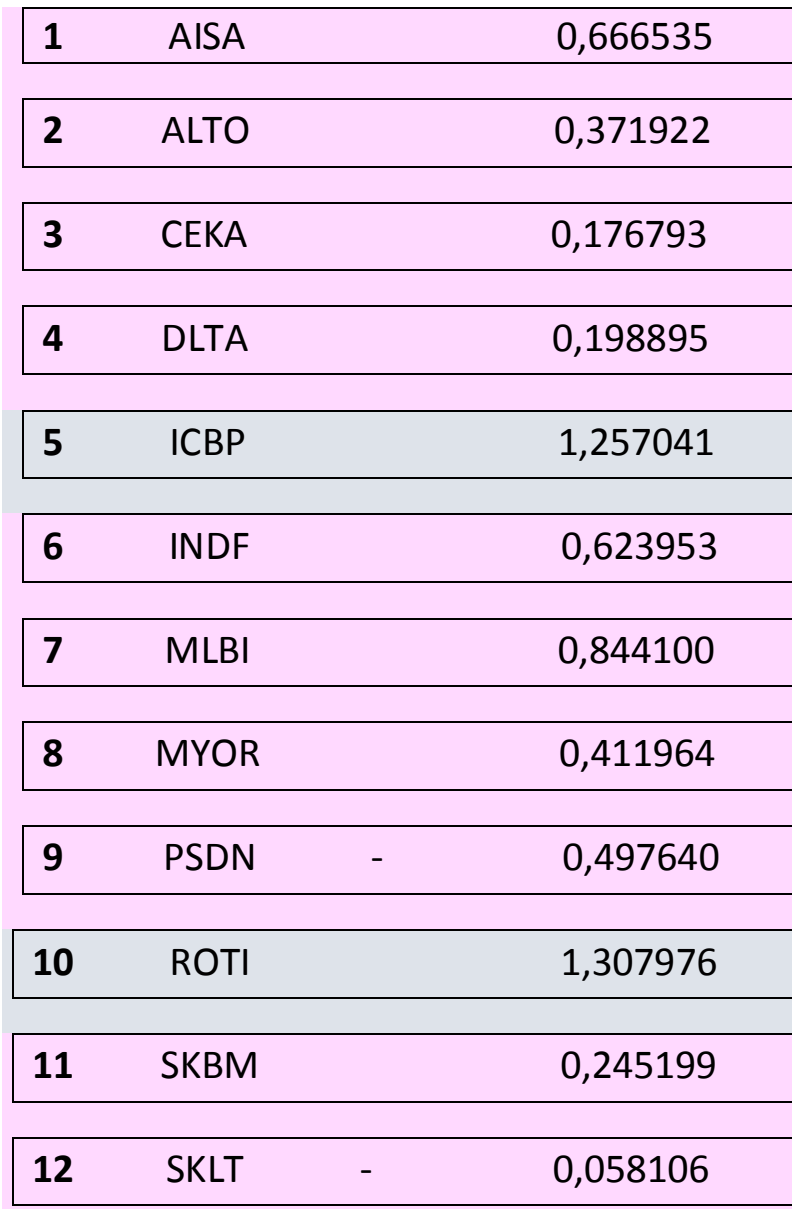

Based on table 4, it shows that of the 14 company stocks sampled all have an average stock risk value $(\beta)$ of 0.551557 . The table illustrates that 2013-2016 had a level of risk or beta less than one $(\beta<1) . \beta<1$ illustrates that it is not easy to change due to market conditions or has a low level of risk. The higher the $\beta$ coefficient, the greater the risk of a stock. 
The company shares that have the highest risk $(\beta)$ are PT. Nippon Indosari Corprindo Tbk (ROTI) which is 1.307976 and the stock with the lowest risk level $(\beta)$ is PT. Prashida Aneka Niaga Tbk (PSDN) amounting to -0.497640 .

5. The expected rate of return

According to Dermawan Sjahrial (2014), the expected rate of return is the rate of return expected by investors in the future on the investment made. In CAPM the expected rate of return is influenced by stock risk. In this case, the calculated risk is only systematic risk as measured by beta $(\beta)$. The expected rate of return using CAPM is the level of risk-free profit Rf plus the risk premium

Table 5. Expected rates of return

\begin{tabular}{clc}
\hline NO & Stock Code & $\mathbf{E ( R i )}$ \\
\hline 1. & AISA & 0,007954 \\
\hline 2. & ALTO & 0,006974 \\
\hline 3. & CEKA & 0,006326 \\
\hline 4. & DLTA & 0,006399 \\
\hline 5. & ICBP & 0,009917 \\
\hline 6. & INDF & 0,007812 \\
\hline 7. & MLBI & 0,008544 \\
\hline 8. & MYOR & 0,007108 \\
\hline 9. & PSDN & 0,004083 \\
\hline
\end{tabular}

Based on table 5, the average expected rate of return from the 14 companies sampled is 0.007572 or $0.76 \%$. Shares of PT. Nippon Indosari Corprindo Tbk (ROTI) has the highest expected rate of return of 0.010066 or $1.01 \%$ and the company that has the lowest expected rate of return is PT. Prashida Aneka Niaga Tbk (PSDN) amounting to 0.004083 or $0.41 \%$. The size of the expected return rate is influenced by the size of the risk of the stock $(\beta)$. The higher the risk $(\beta)$ of a stock, the higher the expected rate of return. This is evidenced by the beta value of the company's shares of PT. Nippon Indosari Corprindo Tbk (ROTI) occupies the highest position, so that in calculating the expected rate of return the company PT. Nippon Indosari Corprindo Tbk (ROTI) also occupies the highest position. The lowest beta value is occupied by shares of PT. Prashida Aneka Niaga Tbk (PSDN), so that the value of the level of return expected by PT. Prashida Aneka Niaga Tbk (PSDN) also occupied the lowest position. This indicates that there is a positive or linear relationship between the expected rate of return and systematic risk or beta. 


\section{Security Market Line (SML)}

Security Market Line (SML) is a line that connects the expected rate of return with systematic risk or individual beta in a balanced market condition (Tandelilin, 2010).

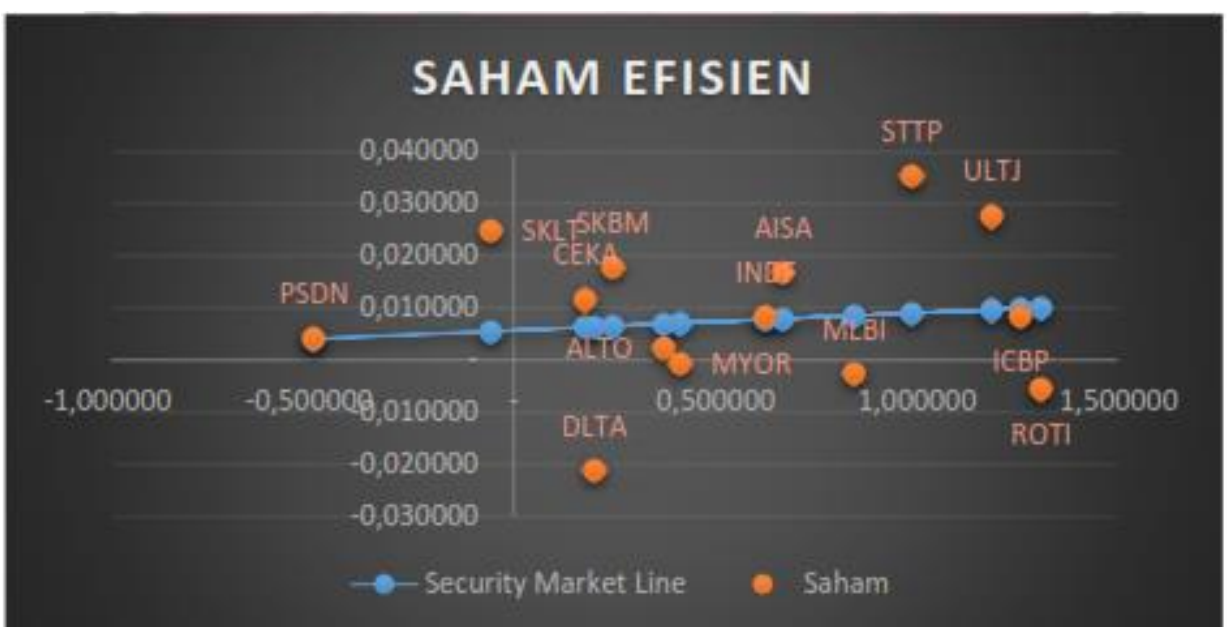

Figure 1. Security Market Line

Based on Figure 1. above, it shows that there is a positive or linear relationship between the expected rate of return and systematic risk or beta. The higher the beta, the higher the expected rate of return. Efficient stocks seen from the SML line are stocks that are above the SML (Security Market Line) and conversely, stocks that are below the SML line are inefficient stocks.

Based on Figure 1., which is included in the efficient stock group seen from the SML line are company stocks with stock codes, namely: AISA, CEKA, INDF, PSDN, SKBM, SKLT, STTP, and ULTJ. Inefficient stock groups are: ALTO, DLTA, ICBP, MLBI, MYOR and ROTI. 


\section{Efficient Stocks and Investment Decisions}

The individual rate of return is greater or less than the expected rate of return.

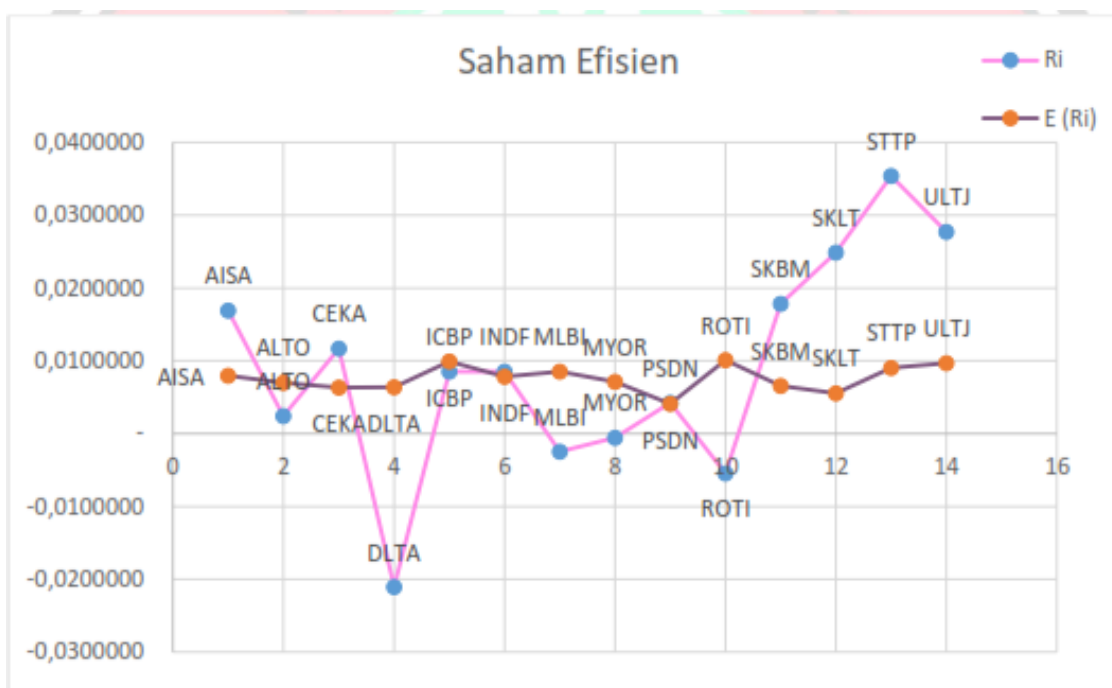

Figure 2. Efficient and Inefficient Stock

Efficient stocks are stocks that have a point (individual rate of return) higher than the point or rate of return which is expected. Conversely, inefficient stocks are shares that own point $\mathrm{Ri}$ (individual rate of return) is lower than point $\mathrm{E}$ (Ri) or expected rate of return.

Based on the picture above, it shows that the stock with the highest Ri point is the stock with the STTP stock code and the stock with the lowest Ri point is the stock with the stock code DLTA. The stock that has the highest E (Ri) point means company shares with code ROTI and shares with point $\mathrm{E}$ ( $\mathrm{Ri}$ ) lowest is the stock company with the code PSDN.

The graph of the expected rate of return or $\mathrm{E}$ ( $\mathrm{Ri}$ ) which is below the chart of the rate of return of individual stocks ( $i$ ), including stocks with stock codes, namely: AISA, CEKA, INDF, SKBM, SKLT, STTP, ULTJ and. PSDN by a very small margin. If Ri> E (Ri)), then the shares are belong to the efficient stock group 
The point of expected rate of return or $\mathrm{E}(\mathrm{Ri})$ which is above the rate of return of individual stocks (Ri) includes stocks with stock codes, namely: ALTO, DLTA, ICBP, MLBI, MYOR, and ROTI. If $\mathrm{Ri}<\mathrm{E}(\mathrm{Ri})$, then These stocks belong to the inefficient stock group.

Efficient stocks are stocks that have a $\mathrm{Ri}$ value greater than $\mathrm{E}(\mathrm{Ri})$ or stocks that have a positive difference. Based on table 6 , it is known that of the 14 companies sampled there are 8 efficient stocks, namely AISA, CEKA, INDF, PSDN, SKBM, SKLT, STTP, and ULTJ. companies with the STTP ticker code are the most efficient stocks because it has the biggest positive difference between $\mathrm{Ri}$ and $\mathrm{E}(\mathrm{Ri})$. Decision the investment taken by investors is to buy shares of efficient (undervalued) stocks and hold it and then sell it again when the security's price rises.

The 6 companies that are included in the inefficient stock group are company shares with the ticker code ALTO, DLTA, ICBP, MLBI, MYOR, and ROTI. Where the company with stock code DLTA is the least efficient stock because it has the biggest negative difference. The investment decision taken is to sell shares in an inefficient (overvalued) stock before the price drops further.

\section{CONCLUSION}

Based on the descriptions that have been disclosed in the results of the analysis and discussion, several conclusions can be drawn, including: Based on the analysis carried out, there is a positive or linear relationship between the expected rate of return and systematic risk $(\beta)$. Where the greater the beta the greater the expected rate of return. This is evidenced by the company's shares that have the highest expected rate of return are shares of PT. Nippon Indosari Corprindo Tbk (ROTI). The calculation of systematic risk $(\beta)$ also shows that the shares of PT. Nippon Indosari Corprindo Tbk (ROTI) also has the highest level of risk. PT. Prashida Aneka Niaga Tbk (PSDN) with the lowest expected rate of return also has the lowest level of risk. The highest individual rate of return is PT. Siantar Top Tbk (STTP) and the stocks with the lowest individual returns are shares of PT. Delta Djakarta Tbk (DLTA). Of the 14 companies sampled, there are 4 stocks that have negative individual returns, namely stocks with the stock code DLTA, MLBI, MYOR, and ROTI. Companies with the stock code STTP are the most efficient stocks, while the least efficient stocks are companies with the stock code DLTA. Meanwhile, based on research conducted on 14 
company stocks sampled, there are 8 efficient stocks, namely stocks with the stock code AISA, CEKA, INDF, PSDN, SKBM, SKLT, STTP, ULTJ, and there are 6 inefficient stocks with the ALTO stock code, DLTA, MLBI, MYOR, ICBP, and BREAD. Where efficient stocks are stocks that have an individual rate of return greater than the expected rate of return. The investment decision taken is to buy stocks efficiently (undervalued) and hold them, then sell them back when the price rises. For inefficient stocks the investment decision taken is to sell the inefficient stock (overvalued) before the price drops.

The results state that there is a linear relationship between the expected rate of return and the systematic risk measured using beta. Where the higher the beta, the higher the expected rate of return. From the processed data, if the stock price of the current period is greater than the previous period, it will produce a high rate of return. The rate of return or return describes or reflects the company's performance. Investors should choose stocks that have a high expected rate of return with less risk and have positive individual returns. Of the 14 shares of Food and Baverage companies for the period 2013-2016, which are eligible for purchase or efficient shares, are companies with the stock codes AISA, CEKA, INDF, PSDN, SKBM, STTP, SKLT, ULTJ. Where companies with the STTP ticker code are the most efficient stocks..

\section{REFERENCES}

Darmadji, Tjiptono dan Hendy M. Fakhruddin. 2012. Pasar Modal di Indonesia Pendekatan Tanya Jawab Edisi 3. Jakarta : Salemba Empat.

Fahmi, Irham. 2015. Manajemen Investasi Teori dan Soal Jawaban Edisi 2. Jakarta : Salemba Empat.

Haidiati, Din. 2016. Penerapan Metode Capital Asset Pricing Model (CAPM) Sebagai Dasar Pengambailan Keputusan Investasi Saham (Studi pada Perusahaan yang Terdaftar di Indeks IDX30 Periode Juli 2012-Juni 2015). Jurnal Administrasi Bisnis (JAB) Vol. 37 No. 2 Agustus 2016. Universitas Brawijaya.

Halim, Abdul. 2015. Analisis Investasi di Aset Keuangan Edisi Pertama. Jakarta : Mitra Wacana Media.

http://yuknabungsaham.idx.co.id diakses tanggal 10 Maret 2017

http://finance.yahoo.com diakses tanggal 10 April 2017 
ABM : International Journal of Administration, Business and Management, Vol. 1 No. 1 November 2019

Jogiyanto. 2010. Teori Portofolio dan Investasi Edisi ketujuh. Yogyakarta : BPFE.

Puspitaningtyas, Zarah. 2015. Prediksi Resiko Investasi Saham. Yogyakarta: Pandiva Buku.

Samsul, Mohamad. 2015. Pasar Modal \& Manajemen Portofolio Edisi 2. Jakarta: Erlangga.

Sekarwati, Herarum. 2016. Pegunaan Metode Capital Asset Pricing Model Dalam Menentukan keputusan Berinvestasi Saham (Studi pada Perusahaan Indeks Kompas 100 di Bursa Efek Indonesia). Skripsi. Universitas Negeri Yogyakarta.

Sjahrial, Dermawan. 2014. Manjemen Keuangan Lanjutan Edisi Revisi. Jakarta : Mitra Wacana Media.

Sugiyono. 2016. Metode Penelitian Pendidikan Pendekatan Kuantitatif, Kualitatif, dan R\&D. Bandung : Alfabeta.

Tandelilin, Eduardus. 2010. Portofolio dan Investasi Edisi Pertama. Yogyakarta : PT Kanisius.

www.bi.go.id diakses tanggal 20 April 2017 www.idx.co.id diakses tanggal 10 April 2017 